\title{
Isolation of an Ustilago maydis gene encoding 3-hydroxy-3-methylglutaryl-coenzyme A reductase and expression of a C-terminal- truncated form in Escherichia coli
}

\author{
Rebecca Croxen, ${ }^{1}$ Michael W. Goosey, ${ }^{1}$ John P. R. Keon ${ }^{2}$ and \\ John A. Hargreaves ${ }^{2}$
}

Author for correspondence: John A. Hargreaves. Tel: +44275 392181. Fax: +44275394007

\footnotetext{
1 Shell Research Ltd, Sittingbourne Research Centre, Sittingbourne, Kent ME9 8AG, UK

2 Department of Agricultural Sciences, University of Bristol, Institute of Arable Crops Research, Long Ashton Research Station, Bristol BS18 9AF, UK
}

\begin{abstract}
A gene encoding 3-hydroxy-3-methylglutaryl-coenzyme A (HMG-CoA) reductase was isolated from the maize fungal pathogen Ustilago maydis. This was accomplished by identifying CDNA and genomic clones that hybridized to an internal fragment of the gene, amplified from $U$. maydis genomic DNA by PCR. The nature of the gene was determined by nucleotide sequence analysis, and by comparing the derived amino acid sequence of the gene with HMG-COA reductases from yeast, and from other organisms. The hydrophobic nature of the $\mathrm{N}$-terminal region of the deduced protein sequence also supported the view that this gene encoded HMG-CoA reductase. A C-terminal-truncated fragment of the $U$. maydis HMG-CoA reductase gene was shown to be expressed in Escherichia coli in a catalytically active form. The expressed protein was also shown to be sensitive to an inhibitor of mammalian HMG-CoA reductase activity.
\end{abstract}

Keywords: basidiomycete, ergosterol biosynthesis, heterologous expression, fungicide, inhibitor target

\section{INTRODUCTION}

Enzymes of the ergosterol biosynthetic pathway have attracted a great deal of attention in recent years, because inhibitors which interfere with their function have been increasingly successful as agricultural fungicides and as antimycotic drugs (Baldwin, 1989; Marriott, 1990). However, virtually all the commercially important antifungal agents affecting sterol biosynthesis act by inhibiting enzymes that function late in the ergosterol biosynthetic pathway (Kelly et al., 1990), that is, the enzymic steps responsible for the conversion of lanosterol to ergosterol. Established targets for antifungal ergosterol biosynthesis inhibitors include C-14 sterol demethylation, $\Delta^{8} \rightarrow \Delta^{7}$ sterol isomerization and $\Delta^{14}$ sterol reduction (Koller, 1992). Squalene epoxidation, which occurs at an earlier stage in sterol biosynthesis, has also been identified as a potential target for antimycotic drugs (Stutz, 1990). In contrast, no selective inhibitors of the earlier steps prior

Abbreviation: HMG-COA, 3-hydroxy-3-methylglutaryl-COA.

The EMBL accession number for the sequence reported in this paper is Z30085. to squalene expoxidation and cyclization have become available for the control of fungal diseases, in either medical or crop protection applications. This is despite an extensive pharmacological interest in the development of therapeutic drugs, directed towards these enzymes, for lowering blood cholesterol levels (Endo, 1985).

3-Hydroxy-3-methylglutaryl-CoA (HMG-CoA) reductase (EC 1.1.1.34) is an enzyme that functions early in sterol biosynthesis. It catalyses the conversion of $(S)-3$ hydroxy-3-methylglutaryl-coenzyme $\mathrm{A}$ to $(R)$-mevalonate. Mevalonate formed by this reaction provides $\mathrm{C}_{5}$ units, used not only in sterol formation, but also for the synthesis of dolichols, ubiquinone, isopentyladenine, haem $\mathrm{A}$ and a diverse array of other isoprenoid metabolites (Panini et al., 1985; Goldstein \& Brown, 1990). Isoprene units derived from mevalonate are also required for post-translational modification of some signalling proteins (Sinensky \& Lutz, 1992). In higher eukaryotes, HMG-CoA reductase is considered to be the key regulatory enzyme of the sterol biosynthesis pathway (Preiss, 1985). It is subject to a number of complex metabolic regulatory mechanisms including translational and transcriptional control (Osborne, 1991; Nakanishi et al., 1988) and modulation of 
enzyme activity by degradation and phosphorylation (Gil et al., 1985; Clarke \& Hardie, 1990; Gillespie \& Hardie, 1992; Sato et al., 1993). The central role played by this enzyme in regulating sterol biosynthesis, and the importance of normal sterol production for growth, makes HMG-CoA reductase an attractive target for the development of new antifungal agents. This view is supported by the fact that yeast (Saccharomyces cerevisiae) mutants devoid of HMG-CoA reductase activity are unable to grow (Basson et al., 1986). Furthermore, a number of antibiotics have been identified as powerful specific competitive inhibitors of HMG-CoA reductase (Endo, 1985 ) and at least two of these, compactin and lovastatin, are effective inhibitors of growth in yeasts (Ikeura et al., 1988).

In eukaryotes, HMG-CoA reductase is an integral mernbrane glycoprotein of the endoplasmic reticulum. Three distinct regions can be recognized within the protein: a membrane anchor $\mathrm{N}$-terminal domain that contains a number (1-8) of hydrophobic regions which correspond to potential trans-membrane regions; a C-terminal catalytic domain, which extends into the cytoplasm ard contains the active site of the enzyme; and a linker region which separates these two domains. In yeast, two structural genes (HMG1 and HMG2) are known to code for HMG-CoA reductase (Basson et al., 1986). In contrast, only a single gene has been found in mammalian genomes (Reynolds et al., 1984), whereas at least three genes, encoding different HMG-CoA reductase isozymes, have been postulated in plants (Bach, 1987). The amino acid sequences of $\mathrm{HMG}-\mathrm{CoA}$ reductases from differert organisms are highly conserved within the C-terminal catalytic domain. In contrast, the $\mathrm{N}$-terminal sequences, in terms of both length and amino acid composition, are diverse (Basson et al., 1988). Nevertheless, despite this lack of homology within the N-terminal region, HMG$\mathrm{CoA}$ reductases from a range of organisms appear to be functionally conserved. For example, HMG-CoA reductases from human, hamster and Arabidopsis thaliana can complement yeast mutants (bmg1, hmg2) lacking HMG-CoA reductase activity (Basson et al., 1988; Learned \& Fink, 1989).

The N-terminal membrane-bound domain, although not necessary for catalytic activity, is required for sterolregulated degradation of the protein (Roitelman et al.. 1992) and for membrane proliferation (Jingami et al.. 1987). HMG-CoA reductase therefore does not need to be associated with a membrane to be catalytically active. Indeed, the HMG-CoA reductase produced by Pseudomonas mevalonii, an organism that utilizes mevalonate as a carbon source, lacks a membrane anchor domain (Beach \& Rodwell, 1989) and proteolytically-cleaved soluble C-terminal fragments of the enzyme from eukaryote sources retain catalytic activity in vivo (Edwards \& Fogelman, 1985). Furthermore, active forms of the catalytic domain of HMG-CoA reductase from hamster and radish (Rbaphanus sativus) have been expressed in Escherichia coli (Darnay \& Rodwell, 1993; Ferrer et al., 1990; Frimpong et al., 1993). Heterologous expression of HMG-CoA reductase activity in this way, in conjunction with site-directed mutagenesis, has already allowed detailed investigations of catalytically important amino acid residues (Darnay et al., 1992; Darnay \& Rodwell, 1993; Wang et al., 1990).

In order to pursue a rational biochemical approach to fungicide design, high yields of pure target enzyme are required to elucidate structure-function relationships, using structural and kinetic data. Recombinant DNA technology offers an attractive route for achieving this goal. In this paper, we report the isolation of an HMGCoA reductase gene from the basidiomycete fungal pathogen Ustilago maydis, and show that a catalytically active, truncated C-terminal fragment of the protein is expressed in a functional form in E. coli. In addition, we demonstrate that the expressed protein is sensitive to a known inhibitor of mammalian HMG-CoA reductase.

\section{METHODS}

Strains, vectors and plasmids. U. maydis strain IMI 103761 (Hargreaves \& Turner, 1989) was used throughout and was grown on YEPD $[1 \%(\mathrm{w} / \mathrm{v})$ yeast extract, $1 \%(\mathrm{w} / \mathrm{v})$ peptone, $2 \%(\mathrm{w} / \mathrm{v})$ dextrose] medium. E. coli strain LE392 [e14- $($ mcr $A)$ bsdR 514 supE44 supF 58 lacY1 or $\Delta$ (lacIZY) 6 galK2 galT22 metB1 $\operatorname{trpR55}$ ] was used for maintaining and screening the genomic library, strain XL1-Blue ( $\operatorname{rec} A 1$ end $A 1$ gyr $A 96$ thi- 1 bsdR 17 supE44 relA1 lac $\left[F^{\prime}\right.$ pro $A B$ lac $\left.\left.I^{q} Z \Delta M 15 \mathrm{Tn} 10\left(\mathrm{Tet}^{r}\right)\right]\right)$ was used for $\mathrm{CDNA}$ library and plasmid manipulations and strain TOP10

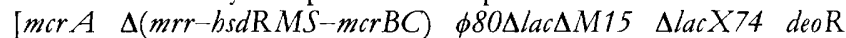
$\operatorname{rec} A 1$ araD139 $\Delta\left(\right.$ ara, leu 7697 galU galK $\lambda^{-}$rpsL end $A 1$ nupG] was used in the expression studies. The $U$. maydis genomic library was constructed in $\lambda$ EMBL3 (Bailey et al., 1994) and the cDNA library was custom synthesized in $\lambda$ ZAPII by Clontech Laboratories. Plasmid pUC18 was used for all subcloning and sequencing procedures and $\mathrm{p} T \mathrm{rcHis} \mathrm{C}$ (Invitrogen Corporation) was used for the expression studies, following the manufacturer's instructions.

DNA procedures. Genomic DNA was extracted from exponentially growing cells as described by Keon et al. (1991). PCR amplification was done using a GeneAmp PCR kit (Perkin Elmer). The reactions were cycled 30 times through $94^{\circ} \mathrm{C}$ for $2 \mathrm{~min}, 58^{\circ} \mathrm{C}$ for $1 \mathrm{~min}$ and $72^{\circ} \mathrm{C}$ for $2 \mathrm{~min}$. At the end of the amplification period the products were analysed by electrophoresis through a $1 \%(\mathrm{w} / \mathrm{v})$ SeaPlaque GTG (FMC BioProducts) agarose gel. Plaque and Southern hybridization, restriction enzyme digestion, ligation and bacterial transformation, and plasmid and bacteriophage $\lambda$ DNA isolation were essentially as described by Sambrook et al. (1989). DNA sequence analysis was performed by the dideoxy-chain termination method of Sanger et al. (1977) using double-stranded plasmid DNA templates, $\left[{ }^{35} \mathrm{~S}\right] \mathrm{d}$ A TP $\alpha$ S and a Sequenase version 2.0 DNA sequencing kit (United States Biochemical). Analysis of DNA sequence data was performed using the University of Wisconsin Genetics Computer Group sequence analysis software package version 7.2. Sequence alignments were derived from a Pearson and Lipman search (Pearson \& Lipman, 1988) using the Tfast A program and a word size of 6 . The Kyte and Doolittle hydropathy measurements (Kyte \& Doolittle, 1982) were determined using the PepPlot program over a window of 21 amino acid residues.

Protein procedures and determination of enzyme activity. SDS-PAGE was performed according to Laemmli (1970), using a $12 \%(\mathrm{w} / \mathrm{v})$ polyacrylamide separating gel and a $4 \%$ stacking 


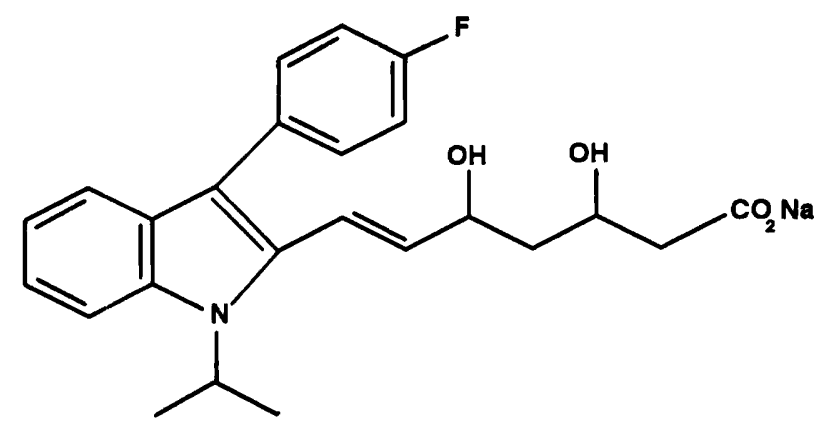

Fig. 1. Structure of WL165748.

gel. Gel dimensions were $7 \mathrm{~cm} \times 8 \mathrm{~cm} \times 0.1 \mathrm{~cm}$ and the gels were run at $200 \mathrm{~V}$ for $45 \mathrm{~min}$. One millilitre of bacterial cell culture was centrifuged at $8000 \mathrm{~g}$ for $1 \mathrm{~min}$, resuspended in $500 \mu \mathrm{l}$ sample buffer and heated to $95^{\circ} \mathrm{C}$ for $5 \mathrm{~min}$. Ten microlitres of this preparation was loaded into each lane. After electrophoresis, proteins were detected by staining the gels with Coomassie Brilliant Blue R-250 (Sigma).

For extraction of HMG-CoA reductase activity, IPTG-induced bacterial cells from a $50 \mathrm{ml}$ culture were pelleted by centrifugation at $8000 \mathrm{~g}$ for $1 \mathrm{~min}$ then resuspended in $5 \mathrm{ml} 20 \mathrm{mM}$ sodium phosphate buffer, pH 7.8, containing $10 \mu \mathrm{M} \quad \beta$ mercaptoethanol, $0 \cdot 25 \%(\mathrm{v} / \mathrm{v})$ Tween $20,10 \mu \mathrm{M}$ phenylmethylsulphonyl fluoride and $0 \cdot 1 \mathrm{mg}$ lysozyme $\mathrm{ml}^{-1}$. Cells were subjected to three cycles of freezing in liquid nitrogen and thawing at $37^{\circ} \mathrm{C}$. Between each cycle the cells were sonicated for $20 \mathrm{~s}$ at $0^{\circ} \mathrm{C}$. The extract was then centrifuged at $100000 \mathrm{~g}$ for $30 \mathrm{~min}$ to remove cell debris. HMG-CoA reductase activity was determined spectrophotometrically by following the oxidation of NADPH (Frimpong et al., 1993). 'The reaction mixture was maintained at $37^{\circ} \mathrm{C}$ and contained $200 \mu \mathrm{mol}$ sodium phosphate buffer, $\mathrm{pH} 7 \cdot 5,10 \mu \mathrm{mol} \beta$-mercaptoethanol and $0.14 \mu \mathrm{mol}$ NADPH in a total volume of $1 \mathrm{ml}$. The reaction was initiated by the addition of $10 \mu 10.3 \mathrm{mM} \mathrm{HMG-CoA}$. In some experiments the inhibitory action of compound WL165748 was tested. This compound (Fig. 1) is a substituted dihydroxy-alklyl-indole derivative described in a patent (WO 84/02131) by the pharmaceutical company Sandoz as an inhibitor of mammalian HMG-CiA reductase.

\section{RESULTS}

\section{Amplification of an internal DNA fragment of a $U$. maydis HMG-CoA reductase gene}

Two sets of 20-mer oligonucleotides $\left({ }^{5} \mathrm{GGA}\right.$ GCT TGT/C TGT GAG/A AAT GT ${ }^{3^{\prime}}$ and ${ }^{3}$ CTG TTC TTT GGT/A CGA/G CGG/A TA ${ }^{5^{\prime}}$ ) were synthesized, using the standard eukaryotic nuclear gene codon assignments, that corresponded to two conserved regions within HMG-COA reductase proteins derived from other organisms. The amino acid sequences encoded by these regions were Gly-Ala-Cys-Cys-Glu-Asn-Val and AspLys-Lys-Pro-Ala-Ala-Ile, respectively, and were located approximately 170 residues apart within the catalytic domain of the protein. Amplification of a corresponding DNA fragment of the $U$. maydis gene(s) was accomplished by PCR, using these primers and U. maydis genomic DNA as a template. A single amplified DNA product (approx. $500 \mathrm{bp}$ ) was obtained, as judged by agarose gel electrophoresis. The size of this product corresponded to an expected size of $517-523 \mathrm{bp}$. The nature of the amplified product was confirmed by Southern hybridization to restriction enzyme digests of cloned HMG-CoA reductase genes from S. cerevisiae (HMG1) in pJR59, A. thaliana in pUCHMG2 and Syrian hamster in pDC56. Strong hybridization signals, corresponding to DNA fragments containing the C-terminal catalytic domains of the genes, were obtained from all the plasmids (data not shown). These results indicated that the PCR product amplified from $U$. maydis genomic DNA corresponded to a region within the catalytic domain of a $U$. maydis HMG-CoA reductase gene.

\section{Isolation and characterization of CDNA clones derived from a $U$. maydis HMG-CoA reductase gene}

The PCR-amplified $U$. maydis DNA fragment was employed as a homologous probe to identify cDNA clones from a $U$. maydis $\lambda Z$ APII library. Approximately 20000 recombinant clones were screened. Two positive plaques $(\lambda 31 \mathrm{~B}$ and $\lambda 41 \mathrm{~B}$ ) were isolated and purified, and

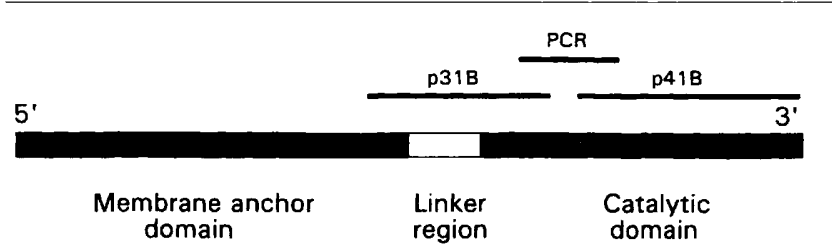

600 b.p.

Fig. 2. Schematic diagram illustrating the position of the CDNA clones, $\mathrm{p} 31 \mathrm{~B}$ and $\mathrm{p} 41 \mathrm{~B}$, in relation to defined regions of the yeast HMG-CoA reductase gene (HMG1); clone p31B overlaps the linker region and the beginning of the catalytic domain, whereas clone p41B corresponds to the $3^{\prime}$ end of the catalytic domain. The clones are separated from each other by about 90 nucleotides. The predicted position of the PCR product, amplified from $U$. maydis genomic DNA, is also marked.

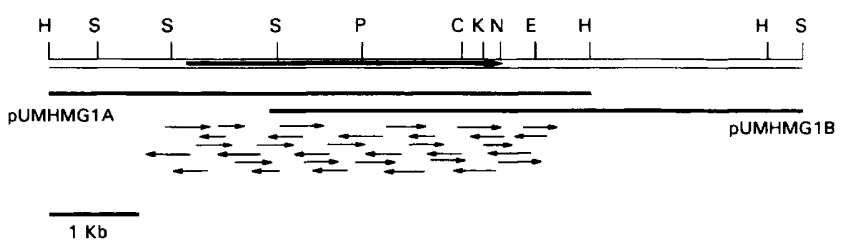

Fig. 3. Partial restriction enzyme map of pUMHMG1A and pUMHMG1B, and the sequencing strategy used to obtain the $U$. maydis HMG-COA reductase gene sequence. Specific oligonucleotide primers, based on the DNA sequence of p31B and $\mathrm{p} 41 \mathrm{~B}$, were employed to initiate sequencing of the region in pUMHMG1A as shown by the small arrows. The position and direction of transcription of the $U$. maydis HMG-CoA reductase is indicated by a bold solid arrow. C, Clal; E, EcoRV; H, HindIII; K, Kpnl; N, Nsil; P, Pstl; S, Sall. 


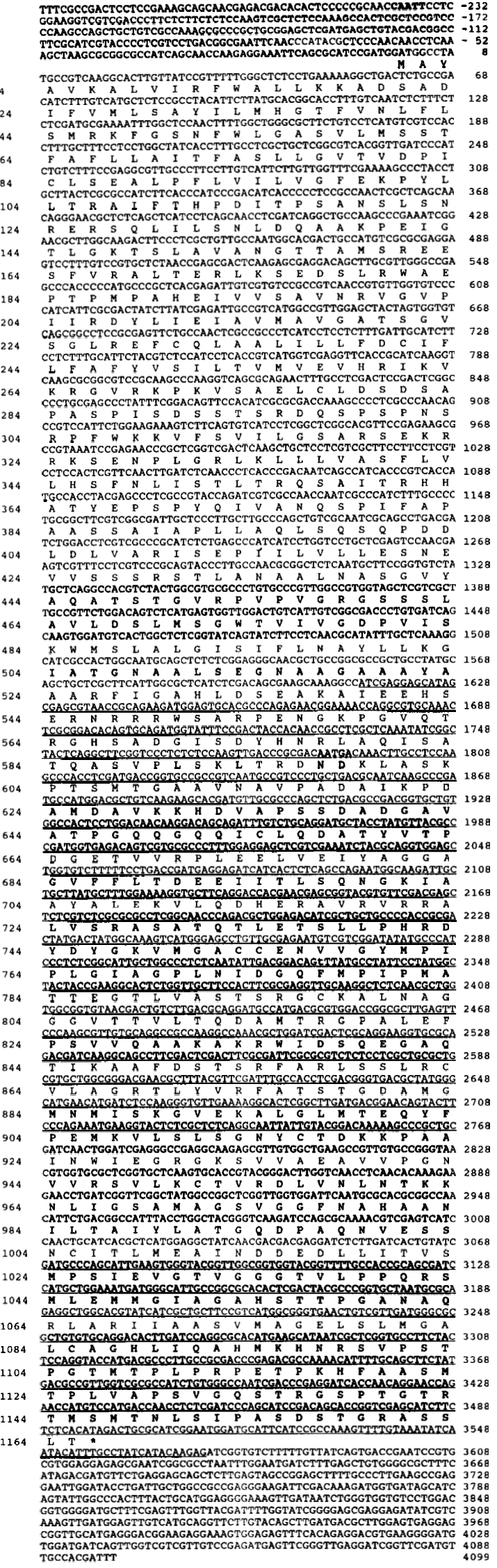

the DNA inserts were recovered by excision on the pBluescript phagemid (plasmids p31B and p41B, respectively). Both clones were sequenced by extension of universal and reverse primers and of specific oligonucleotides. Clone p31B contained a DNA fragment 744 nucleotides long and alignment of the deduced amino acid sequence of this clone with that of the $S$. cerevisiae HMG1 protein revealed homology within the $3^{\prime}$ terminal region of the clone (40.9\% identity over 144 amino acids). This region corresponded to the beginning of the catalytic domain of the HMG1 protein (amino acids 600-714, Fig. 2). In contrast, clone p41B contained a $1126 \mathrm{bp}$ insert which included a poly $(\mathrm{A})^{+}$tail at the $3^{\prime}$ end of the clone. Comparison of the amino acid sequence derived from this clone with that of the $S$. cerevisiae HMG1 protein revealed significant homology between amino acids 744 and 1030 $(65.5 \%$ identity). Alignment of both these sequences with the HMG1 protein, therefore, indicated that $\mathrm{p} 31 \mathrm{~B}$ and $\mathrm{p} 41 \mathrm{~B}$ represented non-overlapping clones derived from the linker and catalytic region of a U. maydis HMG-CoA reductase gene and that these clones were separated from each other by about 90 nucleotides (Fig. 2). There was still the possibility, however, that clones $\mathrm{p} 31 \mathrm{~B}$ and $\mathrm{p} 41 \mathrm{~B}$ originated from two different structural genes encoding HMG-CoA reductase.

\section{Isolation and sequence of the $U$. maydis HMG-CoA reductase gene}

In order to isolate a DNA fragment containing a fulllength $U$. maydis $\mathrm{HMG}-\mathrm{CoA}$ reductase gene, the amplified PCR product was used to screen a $U$. maydis $\lambda$ EMBL3 genomic library (approx. 40000 clones) by plaque hybridization. Three positive clones $(23 \mathrm{~L} 4, \lambda 4 \mathrm{~L} 3$ and 26L3) were identified, after hybridization at a high stringency. Digestion of DNA isolated from the three genomic $\lambda$ clones, with the restriction endonucleases HindIII and SalI, and Southern hybridization analysis using the cDNA clones $\mathrm{p} 31 \mathrm{~B}$ and $\mathrm{p} 41 \mathrm{~B}$ as probes, identified common DNA fragments in clones $\lambda 3 \mathrm{~L} 4, \lambda 4 \mathrm{~L} 3$ and $26 \mathrm{~L} 3$ which hybridized to both cDNA clones (data not shown). A $6.2 \mathrm{~kb}$ HindIII fragment and a $6.0 \mathrm{~kb}$ Sall fragment, derived from $23 \mathrm{~L} 4$, were chosen for further restriction enzyme analysis and subcloned into pUC18 to form pUMHMG1A and pUMHMG1B, respectively (Fig. $3)$. The relevant regions of the DNA inserts in these plasmids were then sequenced on both strands, by extension of specific oligonucleotides as illustrated in Fig. 3 . The nucleotide and deduced amino acid sequence of the gene are shown in Fig. 4. The sequence starts $292 \mathrm{bp}$ upstream of an initiation codon (ATG) and continues

Fig. 4. Nucleotide sequence of the $U$. maydis HMG-COA reductase gene. The deduced amino acid sequence is indicated below the respective codons. Numbers to the right indicate the position relative to the $A$ nucleotide of the initiation codon. Those to the left represent the amino acid position. An open reading frame starts at position 1 (ATG) and continues through to a stop codon (TAG) at position 3496-3498. The position of the cDNA clones, $\mathrm{p} 31 \mathrm{~B}$ and $\mathrm{p} 41 \mathrm{~B}$, are underlined. A putative CAAT box is located at position -240 to -236 . 


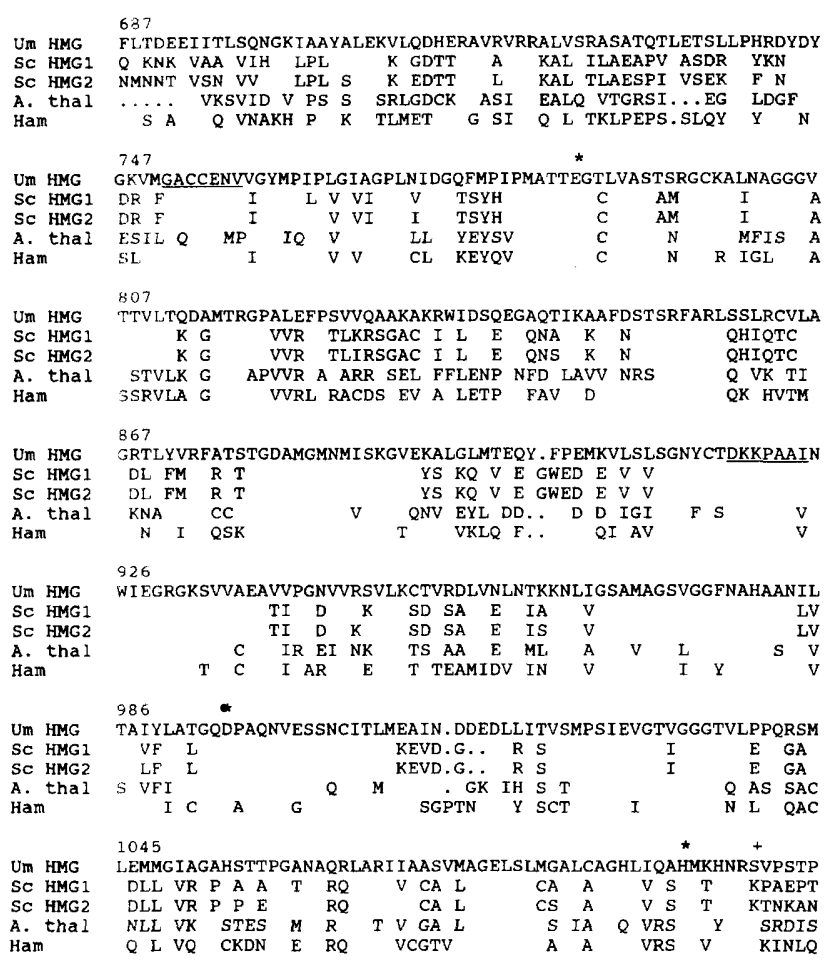

Fig. 5. Comparison of the deduced amino acid sequence of the $U$. maydis HMG-CoA reductase gene with those of the HMGCoA reductase genes from yeast HMG1 and HMG2 (Basson et al., 1988), A. thaliana (Learned \& Fink, 1989) and Syrian hamster (Skalnik \& Simoni, 1985). Only the positions where the sequence of the $U$. maydis HMG-CoA reductase differ are listed for the other species. The underlined residues are those used to design the degenerate PCR primers. Asterisks (*) indicate the positions of the catalytically important histidine, glutamate and aspartate residues; $(+)$ indicates the position of the serine residue which may be phosphorylated. Um, $U$. maydis; $S C, S$. cerevisiae; A. thal, A. thaliana; Ham, Syrian hamster.

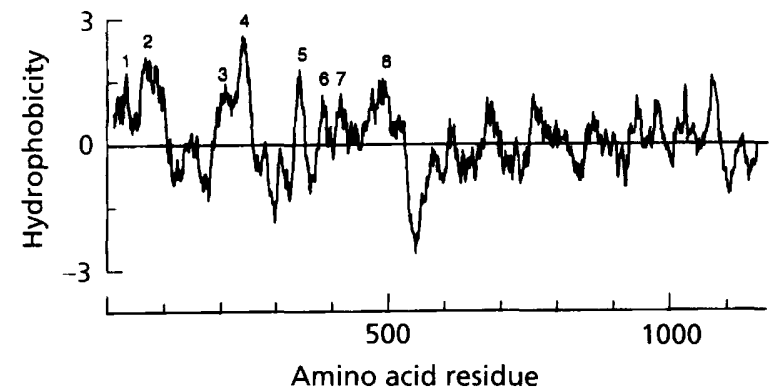

Fig. 6. Hydropathy index plot of the $U$. maydis HMG-CoA reductase protein sequence. The algorithm of Kyte \& Doolittle (1982) was used with a window size of 21 residues. Positive values indicate hydrophobic regions. The hydrophobic domains within the $\mathrm{N}$-terminal region are numbered.

603 bp beyond a stop codon (TAG). A continuous open reading frame begins at position 1 and terminates at position 3495. Three alternative translation initiation sites were identified at amino acid positions 27,34 and 45 .

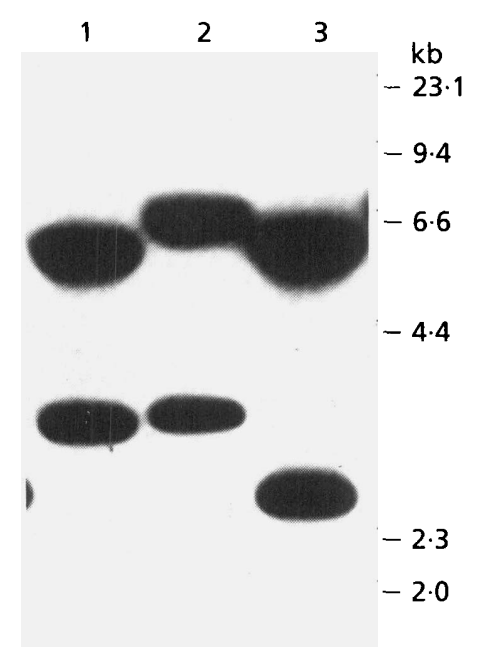

Fig. 7. Southern blot hybridization analysis of $U$. maydis wildtype strain IMI 103761 genomic DNA digested with Sall (lane 1), Pstl (lane 2), and HindIII (lane 3). The DNA fragment amplified from $U$. maydis genomic DNA was radiolabelled and used as the hybridization probe.

However, none of these sites could be differentiated on the basis of the nucleotide sequences surrounding initiation codons optimal for translation initiation in fungi (Ballance, 1991; Gurr et al., 1987; Unkles, 1992). Neither did the location of a putative CAAT motif, at positions -240 to -236 , allow discrimination between these initiation sites. Comparison of the nucleotide sequence of the genomic DNA with those of clones $\mathrm{p} 31 \mathrm{~B}$ and $\mathrm{p} 41 \mathrm{~B}$ revealed that the $\mathrm{cDNA}$ clones were identical to the nucleotide sequences 1615-2358 and 2446-3572, respectively, within the $U$. maydis gene. The positions of $\mathrm{p} 31 \mathrm{~B}$ and $\mathrm{p} 41 \mathrm{~B}$ within the gene sequence are underlined in Fig. 4.

Gap alignment of the deduced amino acid sequence of the $U$. maydis gene with the $S$. cerevisiae HMG1 and HMG2 proteins revealed $62.3 \%$ similarity $(45.4 \%$ identity) and $55 \%$ similarity $(36.7 \%$ identity) respectively. Several stretches of conserved amino acids, also present in HMGCoA reductases from other unrelated organisms, were identified within the C-terminus catalytic domain (Fig. 5). The hydropathy plot of the $U$. maydis protein revealed eight peaks of hydrophobicity within the $\mathrm{N}$-terminus domain (Fig. 6). A similar number of hydrophobic regions have been identified in the S. cerevisiae HMG1 and HMG2 proteins, and seven of these have been recognized as membrane-spanning domains (Sengstag et al., 1990).

Southern analysis of SalI-, PstI- and HindIII-digested $U$. maydis genomic DNA, using the amplified PCR product as a probe, resulted in hybridization patterns which were consistent with there being two related HMG-CoA reductase genes in the $U$. maydis genome (Fig. 7). Both SalI and HindIII digestion resulted in two distinct hybridization bands; only one (a $6.0 \mathrm{~kb} S a l l$ fragment and 


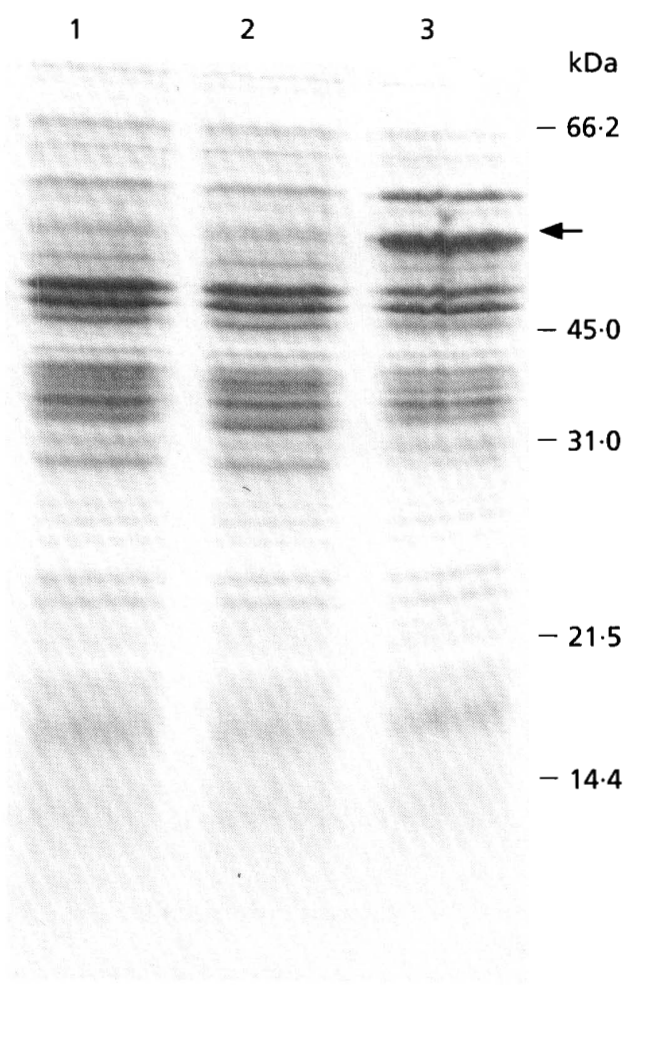

Fig. 8. SDS-PAGE analysis of total protein from $E$. coli cells containing either pTrcHis C (lane 1) or pUMHMG2 (lanes 2 and 3). Proteins in lanes 1 and 3 were extracted after incubation of cells with IPTG at $37^{\circ} \mathrm{C}$ for $3 \mathrm{~h}$. Proteins in lane 2 were extracted from non-induced cells. The arrow marks the position of the new protein produced in induced cells containing pUMHMG2.

a $6.2 \mathrm{~kb}$ HindIII fragment) in each digest corresponded to the genomic clones recovered in this study.

\section{Expression of a C-terminal-truncated $U$. maydis HMG- CoA reductase protein in $E$. coli}

A $2.7 \mathrm{~kb}$ Pst $\mathrm{I}-$ HindIII DNA fragment containing the Cterminal of the U. maydis HMG-CoA reductase gene was inserted, in the correct reading frame, into the prokaryotic expression vector $\mathrm{p} \operatorname{TrcH}$ is $\mathrm{C}$ to form pUMHMG2. This DNA fragment coded for amino acids 655-1165, and therefore constituted a truncated form of the $U$. maydis HMG-CoA reductase, consisting of only the cytosolic catalytic domain of the protein. E. coli cells containing pUMHMG2 synthesized a prominent protein of about $62 \mathrm{kDa}$, as judged by SDS-PAGE, $3 \mathrm{~h}$ after induction with $1 \mathrm{mM}$ IPTG (Fig. 8). This size was in close agreement with the expected size of the truncated HMGCoA reductase $(61 \mathrm{kDa})$. No synthesis of the protein was observed in non-induced cells or in IPTG-induced cells containing pTrcHis $\mathrm{C}$ alone. In addition, extracts of induced cells transformed with pUMHMG2 were found to contain HMG-CoA reductase activity. No activity was detected in non-induced cells. The apparent $K_{m}$ for HMG-
$\mathrm{CoA}$ in induced-cell lysates, as calculated from a reciprocal plot of initial velocity rates versus substrate concentration, was $11.6 \mu \mathrm{M}$. HMG-CoA reductase activity in bacterial cell lysates was inhibited by WL165748, which is a potent inhibitor of mammalian and fungal HMG-CoA reductases (T. E. May, unpublished results), with an $I_{50}$ value of $5 \cdot 4 \mathrm{nM}$.

\section{DISCUSSION}

As reported for S. cerevisiae (Basson et al., 1986) and other fungi (Burmester \& Czempinski, 1994), U. maydis appears, as judged by Southern analysis, to contain two structural genes coding for HMG-CoA reductase. In this study, we describe the isolation and identification of one of these genes. The deduced amino acid sequence of the $U$. maydis HMG-CoA reductase gene exhibited greater overall similarity to the $S$. cerevisiae HMG1 gene product than to the product of the HMG2 gene. However, similar identity to the products of both genes was observed within the $\mathrm{C}$ terminal region $(52.4 \%$ identity over 546 amino acids for HMG1 and $58.1 \%$ identity over 480 amino acids for HMG2). It could, therefore, be argued that the U. maydis gene isolated here is more likely to be equivalent to the S. cerevisiae HMG1 gene than to the HMG2 gene. This conclusion could be confirmed by overexpressing the $U$. maydis gene in S. cerevisiae and determining the effect of its overexpression on the assembly of 'karmellae'. These are a proliferation of stacked membrane pairs, surrounding the nucleus, that are induced by overexpression of the HMG1 gene, but not by overexpression of the HMG2 gene (Wright et al., 1988).

The deduced amino acid sequence of the $U$. maydis HMGCoA reductase gene within the $\mathrm{C}$-terminal domain exhibited several stretches of striking homology to $\mathrm{HMG}$ $\mathrm{CoA}$ reductases from a wide range of other organisms, indicating that these amino acid residues are functionally conserved and may be associated with substrate and/or cofactor binding sites or catalytic activity. Amino acid residues which have already been shown to be important for catalysis in HMG-CoA reductases from $P$. mevalonii and hamster include the histidine residue at amino acid position 1093 (Darnay et al., 1992; Darnay \& Rodwell, 1993), and the glutamate and aspartate residues at positions 786 and 995, respectively (Wang et al., 1990; Frimpong \& Rodwell, 1994). Of particular interest, with respect to the regulation of HMG-CoA reductase activity, is the serine residue at position 1099. This residue is located close to the catalytically important histidine residue. In eukaryotic HMG-CoA reductase, the serine residue at this position is known to be phosphorylated by an AMP-activated protein kinase, resulting in a loss of catalytic activity (Clarke \& Hardie, 1990; Gillespie \& Hardie, 1992; Sato et al., 1993). This suggests that the low activity of phosphorylated HMG-CoA reductase might be due to ionic and/or steric hindrance at the active site of the enzyme (Darnay \& Rodwell, 1993). Interestingly, neither of the $S$. cerevisiae HMG-CoA reductases contains a serine residue at this position in the protein.

The N-terminal region of the $U$. maydis HMG-CoA 
reductase gene contained eight putative hydrophobic domains, as deduced from Kyte and Doolittle hydropathy plots. A similar number of hydrophobic regions have been identified in the $\mathrm{N}$-terminal domain of the $S$. cerevisiae HMG-CoA reductases (Basson et al., 1988). However, only seven of these eight hydrophobic regions have been recognized as possible transmembrane domains (Sengstag et al., 1990). In contrast, eight membrane-spanning domains have been implicated in higher eukaryote HMGCoA reductases (Roitelman et al., 1992; Olender \& Simoni, 1992). The membrane-spanning region, besides anchoring the protein to the endoplasmic reticulum, also serves a number of other functions. For example, in mammalian cells, the membrane-bound portion of the protein is required for sterol-regulated proteolytic degradation of the enzyme (Gil et al., 1985). The N-terminal region of the protein is also important, in both $S$. cerevisiae and mammalian cells, for triggering increased membrane synthesis (Anderson et al., 1983; Wright et al., 1988). Structural similarities between the membrane-associated domain of HMG-CoA reductases and other eukaryotic transmembrane proteins that interact with heterotrimeric GTP-binding proteins have been noted (Sengstag et al., 1990), and this similarity could imply that HMG-CoA reductase has a role in information transfer within the cell.

The hrdrophobic N-terminal domain of HMG-CoA reductases is not necessary for the catalytic activity of the enzyme. Indeed, soluble preparations of the enzyme from tissues often contain a proteolytically-derived fragment of the native protein (Edwards \& Fogelman, 1985) and this property of the enzyme has been exploited to gain high levels of expression of active HMG-CoA reductases in heterologous systems (Darnay \& Rodwell, 1993; Ferrer $e t$ al., 1990); Frimpong et al., 1993). A C-terminal fragment of the $U$. maydis HMG-CoA reductase was similarly catalytically active when expressed in E. coli in the present study. The $K_{\mathrm{m}}$ value calculated for this recombinant protein was similar to the value obtained for HMG-CoA isolated from rat liver $\left(K_{\mathrm{m}}=9 \cdot 1 \mu \mathrm{M}\right.$; Endo, 1985). In addition, the truncated form of the protein was shown to be sensitive to an inhibitor of mammalian HMG-CoA reductases.

Expression of a catalytically active form of the $U$. maydis HMG-CoA reductase in E. coli now provides a reliable source of active enzyme in quantities necessary for more detailed kinetic and inhibitor studies. In addition, the availability of a regular supply of recombinant enzyme, in conjunction with a simple spectrophotometric assay, should enable automated procedures to be developed for routine in vitro screening of potential inhibitors of fungal HMG-CoA reductases.

\section{ACKNOWLEDGEMENTS}

We would like to thank J. Rine (University of California, USA) for plasmid pJR59, G. R. Fink (Whitehead Institute, USA) for plasmid pUCHMG2' and K. T. Chun (Stanford University, USA) for plasmid pDGS6. We would also like to thank D. Whitaker for technical support and D. Hendry for synthesis of WL165748.

\section{REFERENCES}

Anderson, R. G. W., Orci, L., Brown, M. S., Garcia-Segura, L. M. \& Goldstein, J. L. (1983). Ultrastructural analysis of crystalloid endoplasmic reticulum in UT-1 cells and its disappearance in response to cholesterol. J Cell Sci 63, 1-20.

Bach, T. J. (1987). Synthesis and metabolism of mevalonic acid in plants. Pl Physiol Biochem 25, 163-178.

Bailey, A. M., Burden, R. S., James, C. S., Keon, J. P. R., Croxen, R., Bard, M. \& Hargreaves, J. A. (1994). Isolation of the ERG2 gene, encoding $\Delta^{8} \rightarrow \Delta^{7}$ sterol isomerase, from the maize smut pathogen, Ustilago maydis. Exp Mycol 18, 87-92.

Baldwin, B. C. (1989). Inhibitors of ergosterol biosynthesis as crop protection agents. Biochem Soc Trans 18, 61-62.

Ballance, D. J. (1991). Transformation systems for filamentous fungi and an overview of fungal gene structure. In Molecular Industrial Mycology: Systems and Applications for Filamentous Fungi, pp. 1-29. Edited by S. A. Leong \& R. M. Berka. New York: Marcel Dekker.

Basson, M. E., Thorsness, M. \& Rine, J. (1986). Saccharomyces cerevisiae contains two functional genes encoding 3-hydroxy-3methylglutaryl-coenzyme A reductase. Proc Natl Acad Sci US A 83, 5563-5567.

Basson, M. E., Thorsness, M., Finer-moore, J., Stroud, R. M. \& Rine, J. (1988). Structural and functional conservation between yeast and human 3-hydroxy-3-methylglutaryl coenzyme A reductases: the rate-limiting enzyme of sterol biosynthesis. Mol Cell Biol 8, 3797-3808.

Beach, M. J. \& Rodwell, V. W. (1989). Cloning, sequencing, and overexpression of mvaA, which encodes Pseudomonas mevalonii 3hydroxy-3-methylglutaryl coenzyme A reductase. J Bacteriol 171, 2994-3001.

Burmester, A. \& Czempinski, K. (1994). Sequence comparison of a segment of the gene for 3-hydroxy-3-methylglutaryl-coenzyme $A$ reductase in zygomycetes. Eur J Biochem 220, 403-408.

Clarke, P. R. \& Hardie, D. G. (1990). Regulation of HMG-CoA reductase: identification of the site phosphorylated by the AMPactivated protein kinase in vitro and in intact rat liver. EMBO J9, 2439-2446.

Darnay, B. G. \& Rodwell, V. W. (1993). $\mathrm{His}^{865}$ is the catalytically important histidyl residue of syrian hamster 3-hydroxy-3methylglutaryl-coenzyme A reductase. $J$ Biol Chem 268, 8429-8435.

Darnay, B. G., Wang, Y. \& Rodwell, V. W. (1992). Identification of the catalytically important histidine of 3-hydroxy-3-methylglutarylcoenzyme A reductase. J Biol Chem 267, 15064-15070.

Edwards, P. A. \& Fogelman, A. M. (1985). Studies on purified mammalian HMG-CoA reductase and regulation of enzyme activity. In Regulation of HMG-CoA Reductase, pp. 133-148. Edited by B. Preiss. Orlando, FL: Academic Press.

Endo, A. (1985). Specific nonsterol inhibitors of HMG-CoA reductase. In Regulation of HMG-CoA Reductase, pp. 49-78. Edited by B. Preiss. Orlando, FL: Academic Press.

Ferrer, A., Aparicio, C., Nogues, N., Wettstein, A., Bach, T. J. \& Boronat, A. (1990). Expression of catalytically active radish 3hydroxy-3-methylglutaryl-coenzyme A reductase in Escherichia coli. FEBS Lett 266, 67-71.

Frimpong, K. \& Rodwell, V. W. (1994). Catalysis by syrian hamster 3-hydroxy-3-methylglutaryl-coenzyme A reductase: proposed roles of histidine 865 , glutamate 558 and aspartate 766. J Biol Chem 259, 11478-11483.

Frimpong, K., Darney, B. G. \& Rodwell, V. W. (1993). Syrian hamster 3-hydroxy-3-methylglutaryl-coenzyme $A$ reductase ex- 
pressed in Escherichia coli: production of homologous protein. Protein Lixpression Purif 4, 337-344.

Gil, G., Faust, J. R., Chin, D. J., Goldstein, J. L. \& Brown, M. S. (1985). Membrane-bound domain of HMG-CoA reductase is required for sterol-enhanced degradation of the enzyme. Cell 41, 249-258.

Gillespie, J. G. \& Hardie, D. G. (1992). Phosphorylation and inactivation of $H M G-C o A$ reductase at the AMP-activated protein kinase site in response to fructose treatment of isolated rat hepatocytes. FEBS Lett 306, 59-62.

Goldstein, J. L. \& Brown, M. S. (1990). Regulation of the mevalonate pathway. Nature 343, 425-430.

Gurr, S. J., Unkles, S. E. \& Kinghorn, J. R. (1987). The structure and organization of nuclear genes of filamentous fungi. In Gene Structure in Eukaryotic Microbes, pp. 93-139. Edited by J. R. Kinghoen. Oxford \& Washington: IRL Press.

Hargreaves, J. A. \& Turner, G. (1989). Isolation of the acetyl-CoA synthetase gene from the corn smut pathogen, Ustilago maydis. J Gen Microbiol 135, 2675-2678.

Ikeura, R., Murakawa, S. \& Endo, A. (1988). Growth inhibition of yeast by compactin (ML-236B) analogues. J Antibiot 41, 1148-1150.

Jingami, H., Brown, M. S., Goldstein, J. L., Anderson, R. G. W. \& Luskey, K. L. (1987). Partial deletion of membrane-bound domain of 3-hydroxy-3-methylglutaryl coenzyme A reductase eliminazes sterol-enhanced degradation and prevents formation of crystalloid endoplasmic reticulum. J Cell Biol 104, 1693-1704.

Kelly, S. L., Kenna, S., Bligh, H. F. J., Watson, P. F., Stansfield, I., Ellis, S. W. \& Kelly, D. E. (1990). Lanosterol to ergosterol enzymology, inhibition and genetics. In Biochemistry of Cell $W_{\text {cills }}$ and Membranes in Fungi, pp. 223-243. Edited by P. J. Kuhn, A. P. J. Trinci, M. J. Jing, M. W. Goosey \& L. G. Copping. Berlin: Springer-Verlag.

Keon, J. P. R., White, G. A. \& Hargreaves, J. A. (1991). Isolation, characterization and sequence of a gene conferring resistance to the systemic fungicide carboxin from the maize smut pathogen, Ustilago maydis. Curr Genet 19, 475-481.

Koller, W. (1992). Antifungal agents with target sites in sterol functions and biosynthesis. In Target Sites of Fungicide Action, Fp. 191-206. Edited by W. Koller, Boca Raton, FL: CRC Press.

Kyte, J. \& Doolittle, R. F. (1982). A simple method for displaying the hydropathic character of a protein. J Mol Biol 157, 105-132.

Laemmli, U. K. (1970). Cleavage of structural proteins during the assembly of the head of bacteriophage T4. Nature 227, 680-685.

Learned, R. M. \& Fink, G. R. (1989). 3-Hydroxy-3-methylglutarylcoenzyme A reductase from Arabidopsis thaliana is structurally distinct from the yeast and animal enzymes. Proc Natl Acad Sci US.A 86, 2779-2783.

Marriott, M. S. (1990). The rational design of fungal lanosterol C14 demethylase inhibitors. In Molecular Aspects of Cbemotherapy, FP. 193-204. Edited by E. Borowski \& D. Shugar. New York: Pergamon Press.

Nakanishi, M., Goldstein, J. L. \& Brown, M. S. (1988). Multivalent control of 3-hydroxy-3-methylglutaryl coenzyme A reductase: mevalonate-derived product inhibits translation of mRNA and accelerates degradation of enzyme. J Biol Chem 263, 8929-8937.

Olender, E. H. \& Simoni, R. D. (1992). The intracellular targeting and membrane topology of 3-hydroxy-3-methylglutaryl-CoA reductase. J Biol Chem 267, 4223-4235.
Osborne, T. F. (1991). Single nucleotide resolution of sterol regulatory region in promoter for 3-hydroxy-3-methylglutaryl coenzyme A reductase. J Biol Chem 266, 13947-13951.

Panini, S. R., Rogers, D. H. \& Rudney, H. (1985). Regulation of HMG-CoA reductase and the biosynthesis of nonsteroid prenyl derivatives. In Regulation of HMG-Co.A Reductase, pp. 149-181. Edited by B. Preiss. Orlando, FL: Academic Press.

Pearson, W. R. \& Lipman, D. J. (1988). Improved tools for biological sequence comparison. Proc Natl Acad Sci USA 85, 2444-2448.

Preiss, B. (1985). Regulation of HMG-CoA Reductase. Orlando, FL: Academic Press.

Reynolds, G. A., Basu, S. K., Osborne, T. F., Chin, D. J., Gil, G., Brown, M. S., Goldstein, J. L. \& Luskey, K. L. (1984). HMG-CoA reductase: a negatively regulated gene with unusual promoter and $5^{\prime}$ untranslated regions. Cell 38, 275-285.

Roitelman, J., Olender, E. H., Bar-nun, S., Dunn, W. A. \& Simoni, R. D. (1992). Immunological evidence for eight spans in the membrane domain of 3-hydroxy-3-methylglutaryl coenzyme A reductase: implications for enzyme degradation in the endoplasmic reticulum. J Cell Biol 117, 959-973.

Sambrook, J., Fritsch, E. F. \& Maniatis, T. (1989). Molecular Cloning: a Laboratory Manual, 2nd end. Cold Spring Harbor, NY: Cold Spring Harbor Laboratory.

Sanger, F., Nicklen, S. \& Coulson, A. R. (1977). DNA sequencing with chain-terminating inhibitors. Proc Natl Acad Sci USA 74, 5463-5467.

Sato, R., Goldstein, J. L. \& Brown, M. S. (1993). Replacement of serine-871 of hamster 3-hydroxy-3-methylglutaryl-CoA reductase prevents phosphorylation by AMP-activated kinase and blocks inhibition of sterol synthesis induced by ATP depletion. Proc Natl Acad Sci US A 90, 9261-9265.

Sengstag, C., Stirling, C., Schekman, R. \& Rine, J. (1990). Genetic and biochemical evaluation of eucaryotic membrane protein topology: multiple transmembrane domains of Saccharomyces cerevisiae 3-hydroxy-3-methylglutaryl coenzyme A reductase. Mol Cell Biol 10, 672-680.

Sinensky, M. \& Lutz, R. J. (1992). The prenylation of proteins. BioEssays 14, 25-31.

Skalnik, D. G. \& Simoni, R. D. (1985). The nucleotide sequence of the syrian hamster HMG-CoA reductase. DN A 4, 439-444.

Stutz, A. (1990). Allylamine derivatives - inhibitors of fungal squalene epoxidase. In Molecular Aspects of Chemotherapy, pp. 205-213. Edited by E. Borowski \& D. Shugar. New York: Pergamon Press.

Unkles, S. E. (1992). Gene organization in industrial filamentous fungi. In Applied Molecular Genetics of Filamentous Fungi, pp. 28-53. Edited by J. R. Kinghorn \& G. Turner. London \& Glasgow: Blackie Academic \& Professional.

Wang, Y., Darney, B. G. \& Rodwell, V. W. (1990). Identification of the principal catalytically important acidic residue of 3-hydroxy-3methylglutaryl coenzyme A reductase. I Biol Chem 265, 21634-21641.

Wright, R., Basson, M., D'ari, L. \& Rine, J. (1988). Increased amounts of HMG-CoA reductase induce 'Karmellae': a proliferation of stacked membrane pairs surrounding the yeast nucleus. J Cell Biol 107, 101-114.

Received 28 March 1994; accepted 12 May 1994. 